\title{
Designing Digital Mechanisms for Managing the Backup System, Risks, Synergies
}

\author{
Evgenij Yur'evich Moskvitin*, Victor Tkach
}

\author{
Don State Technical University in Shakhty, Shahty, Russia \\ *Corresponding author. Email: djulm@rambler.ru
}

\begin{abstract}
A system of digital mechanisms for transforming and managing economic information is given: a digital platform, matrix and mega-balance digital mechanisms: transforming reporting and accounting into international and national standards, hedged, integrated risks and synergistic mega-balances. The system of mega-accounts based on the concept of net assets and liabilities is considered. A hedged-risky digital mega-balance for managing the reserve system and risks has been developed.
\end{abstract}

Keywords: Digital platform, technologies, mechanisms. Digital tools: matrix megabalances. Digital megabalances: hedged, integrated risk, synergetic. Computer program for the implementation of national and federal target programs.

\section{INTRODUCTION}

In modern conditions in the global economy, 6 types of digital accounting have been designed: triple, threelevel, engineering, mega, stereo and digital itself/

Digital accounting of any kind includes the following components:

- digital platform in most cases engineering chart of accounts;

- digital technologies, algorithmic accounting types: strategic, managerial, transactional, intellectual, social, environmental, behavioristic and any other type of activity, depending on the needs of participants in the digital behavioral economy;

- digital mechanisms in a complex form the appropriate technology;

- digital cloud for storing information and functioning of predictive analytics;

- distributed registers designed to solve specific problems in a structural context: implementation of national projects at the level of vice-prime ministers, governors, municipalities, etc.

The basis of the digital accounting system is digital mechanisms that provide a solution to 5 defining functions of digitalization:
- multilevel (state, enterprise, citizen);

- multifunctionality: financial, social, environmental, behavioristic, transactional, ect.;

- instantaneous nature of functioning;

- $\quad$ predictive nature of management;

- $\quad$ synergy of the digital organization system.

Analysis of literature sources and patent activity

Organization, construction and design of digital accounting are discussed in works $[9,13,15,16,19,24$, $29,34,44,47,48]$.

The classification, design and operation of platforms are considered in works [6, 17, 18, 39, 41, 44, 65. 68].

Various types of digital technologies are presented in works $[2,5,6,20,27,30,31,35,36,37,40,53,58$, $61,62]$.

Digital tools, algorithms, aggregated iterations are considered in the works of many researchers $[3,10,13$, 19, 21, 22, 26, 42, 44, 55, 59, 63].

Optimum, equilibrium, synergy and methods of their measurement and use in digital accounting are presented in the works $[33.38,44]$.

Patent activity is considered in the works $[2,19,20$. 44]. 


\section{System of digital mechanisms (mega-balances)}

The basis for the functioning of digital accounting, control and analysis systems is:

1. Digital platform: engineering chart of accounts.

2. Databases: private. corporate, territorial, international.

3. Digital technologies.

4. The system of digital mechanisms, providing online functioning of any economic processes, phenomena and objects (more than 500).

5. Distributed ledger.

6. Permanent recording.

Digital mechanisms are classified into:

I. Engineering systems:

Behavioral: structural, behavioral, consumer, educational, intellectual and other mega-balances of a digital type;

Transactional: strategic; reserve; semantic; innovative; synergistic, etc. mega-balances.

II. Digital mechanisms, matrix type: matrices for convening reporting forms into international and national standards, determining synergies, managing the reserve system and risks on a parity basis.

III. Control digital mechanisms in the form of a system of digital mega-balances.

IV. Decision-Making Mechanisms: Predictive Digital Mega-balances,

Digital mechanisms are characterized by the following qualimetric characteristics:

I. Economic: engineering structured chart of accounts; mega-accounts: economic aggregates and aggregated transactions; net intellectual assets and liabilities; safety margins, areas of financial risk; synergistic effect.

II. Legal: focus on the legal component: order on accounting policy, financing, incentives, results, smart contracts (roadmap, effective contract, etc.).

III. Informational: engineering chart of accounts, measuring qualimetry, mega-accounts, aggregated accounting entries.

IV. Technological: initial and final operator, a set of aggregates, a system of algorithms, transformation matrices in IFRS, etc.

V. Management: management of economic processes, financial, intellectual. social, environmental capital. predictive analytics.
VI. Optimization: use of human capital (intellectual, structural, behavioral, educational mega-balances), Equilibrium (system of digital mega-balances), synergy (synergistic megabalance).

VII. Motivational: intellectual net assets and liabilities, capital in a fair assessment (intellectual. behavioral, educational, structural and consumer, digital mega-balances).

Digital mechanisms integrated into financial, managerial, tax accounting are widely used in a wide variety of forms: financial balances (France, Spain); integrated risk balances (Japan, Korea); digital tax balances (Poland); zero balances (Germany, Netherlands); growth asset balance sheets (US); semantic balances (Canada, USA).

More than 500 types of digital mechanisms are registered with the Rospatent of the Russian Federation, which makes it possible to determine, take into account and manage a set of a wide variety of factors in the organization's activities:

- social, political and regulatory factors;

- $\quad$ strengths and weaknesses;

- state and dynamics of structural, behavioral, educational, intellectual and consumer capital;

- management of financial risk zones;

- implementation of federal target programs;

- effective contract management:

- $\quad$ state and dynamics of intellectual capital;

- condition and management of financial condition;

- roadmap management;

- management of loans, subsidies, subventions, etc.

Digital mechanisms integrated into financial, management and tax accounting can be used:

In digital control and real-time control:

- financial condition diagnostics: monitoring megabalance;

- building a comprehensive system of cost and income management by types of incomegenerating activities: gradualistic mega-balance;

- management accounting using the systems "direct costing", "standard costing", "kaizen costing", etc.:

- management of financial responsibility centers: mega-balance of the CFD:

- organization of a budgetary financing control system: subsidiary, budgetary, grand megabalances; 
- management of structural, behavioral, educational and consumer capital: the system of megabalances;

- investment management: investment megabalance;

- summing up the results of work of internal divisions:

- control over the implementation of federal target programs: target, subsidiary mega-balances;

- control over the use of special funds and targeted financing.

In general, digital mechanisms are focused on managing changes in national capital (financial, intellectual. environmental, social), as a single indicator of the effectiveness of the implementation of national projects, the use of budget funding, the evaluation of various competitions, etc.

Moreover, digital enforcement mechanisms for the use of Russian taxpayers' funds exclude any possibility of corruption.

Organization of general digital control:

- brand performance management: digital branding;

- management of performance indicators in the field of research and technological work: innovative, intellectual, structural, behavioral mega-balances;

- management of indicators of international and national recognition: prestigious, synergistic, brand mega-balances;

- management of indicators of economic and financial stability, solvency, funds, etc. (system of digital mega-balances: monitoring, hedged, immunization).

Digital management and control over the use of property:

- non-current assets, circulating assets, funds, intellectual capital (organic, market megabalances):
- net assets and net liabilities (synergistic megabalance).

Digital management of reorganization processes with the definition of results (synergy, anergism) based on the use of engineering mechanisms integrated into financial. management and tax accounting: synergistic, reorganization, innovative mega-balances.

\section{MATRIX DIGITAL MECHANISMS}

Matrix calculus and transformations in the digital accounting system have been used in the world economy for more than 30 years and boil down to the following main areas:

- matrices of distribution of counter services of auxiliary shops;

- matrices of correspondence of accounts of different countries (England - Germany, Russia - Germany. etc.)

- transformation matrices into international accounting standards (lFRS);

- 5 matrices for convening national reporting into IFRS.

Figure 1 characterizes the use of matrices in three cases.

Comparison of accounting systems of different countries or one of the countries with IFRS.

Matrix of conversion to IFRS.

System of matrices for preparation of national reporting with IFRS.

The qualimetric model of the system of digital mega-balances and matrices is based on the assumption that in the let century, experts position accounting and finance as the first and main direction of management, followed by other types: business economics (theoretical justification), comparative management, labor relations and methods management, production management, marketing, management information systems, organizational behavior, strategy. 


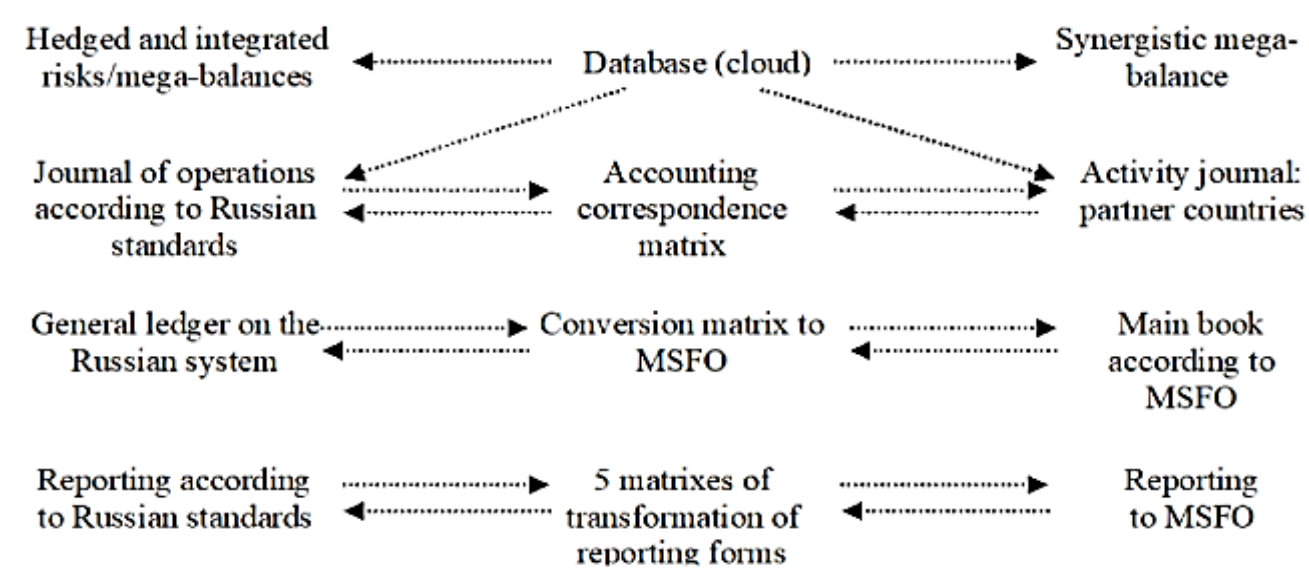

Figure 1 Matrix and mega-balance digital mechanisms

The qualilnetric model "Characteristics of the system of digital accounting instruments" divides the entire toolkit into two groups, depending on the chosen method for assessing the results of the organization's activities [44]:

- valuation based on assets and their changes (in book and market value):

- valuation based on the synergy effect determined by the change in net liabilities (in market and fair value).

- As a result, all digital tools are focused on managing the value of the enterprise in the book, market and fair value of the enterprise. which meets the requirements of the 1 st and 2 nd laws of capitalism:

- participation of market entities in the created national income (entrepreneurs $30 \%$. state $50 \%$, workers 20\%);

- ensuring the accumulation of the created national income by all participants of the cost of 1 average annual income for 6 years.

All digital mechanisms in accordance with the legislation are focused on the management and control of the decision of these economic laws of society.

\section{MATERIALS AND METHODS}

\subsection{Digital mechanisms for managing and monitoring the execution of national projects}

In the Russian Federation, huge resources are allocated for the implementation of national projects ( 26 trillion rubles), recovery of the economy from the consequences of the coronavirus (5 trillion rubles), budgetary financing of education, healthcare, etc.

The control of their use is carried out according to the principle: financing, use, supporting documents for hundreds of scattered indicators, without determining the final result.
On the Internet, 7 million results are determined for the request for the implementation of national projects.

The Ministry of Economic Development develops 15 performance indicators for the implementation of national projects (15 KPIs, $15 \mathrm{KPIs}$ ).

In a market economy and digitalization, this indicator is the created national capital, which includes all types of capital: intellectual, social, human, environmental, cultural, educational, etc.

DSTU has developed a system of digital mechanisms for managing national capital, aimed at concentrating resources, which puts Russia on a growth trajectory.

Consider the formation of a digital mechanism and algorithm "Digital mechanism for the implementation of federal target programs" (property of DSTU, developed by Professor Emeritus V.I. Tkach), based on intellectual capital.

Initial Operator: University Engineering Chart of Accounts Mega-Account Balances:

- mega-account I-00-00-000, "Intellectual assets";

- mega-account II-00-00-000, "Intellectual obligations";

- mega-account III-00-00-000. "Intellectual capital";

- mega-account IV-00-00-000, "Synergetic effect".

Mega-accounts are built on the concept of net intellectual assets and liabilities with an orientation based on the balance equation of national capital:

$$
\begin{gathered}
\mathrm{A}=\mathrm{K}+\mathrm{O} . \\
\mathrm{A}-\mathrm{O}=\mathrm{CHa}, \\
\mathrm{CHp}=\mathrm{Kc.o.},
\end{gathered}
$$

where A - intellectual assets;

$\mathrm{O}$ - intellectual obligations;

$\mathrm{K}$ - intellectual capital (structural, behavioral, educational); 


\section{CHa-net assets;}

CHp-net liabilities;

Kc.o. - intellectual capital in a fair assessment.

Analytical mega-accounts of the first order: I-00; II00; III-00 provide accounting and management of intellectual capital, net assets and net liabilities by faculty.

Analytical mega-accounts of the second order are intended for the management of intellectual capital, net intellectual liabilities and net intellectual assets in the context of departments and staff of departments: I-0000, II-00-00; III-00-00.

Analytical mega-accounts of the third order are designed to take into account the basic criteria and the value of intellectual capital obtained during the implementation of federal (subjects of the federation, municipalities, etc.) target programs in the context of individual positions of intellectual capital (publications of the RSCI, Web of Science, SCOPUS and others): I00-00-000; II-00-00-000; III-00-000.

\section{For example:}

I-01-01-001 "Intellectual assets" obtained as a result of the publication of the SCOPUS article articles (001) of department 01 , faculty 01 .

III-01-01-001- means the formation of intellectual capital as a result of the publication of an article in SCOPUS article (001) by an employee of the department 01 , faculty 01 .

The computer program for management of the implementation of federal target programs by teaching staff, departments, faculties and the resulting intellectual capital, synergetic effect is characterized by 14 typical iterations:

1st iteration: Reflection of the process of creating intellectual capital and intellectual assets in the process of implementing the federal target program in the context of indicators (faculties. departments, employees):

Debit of mega-account I-00-00-000 "Intellectual assets"

Credit mega-account III-00-00-000 "Intellectual Capital"

2nd iteration: Creating intellectual capital and reflecting the resulting intellectual obligations:

Debit of the mega-account II-00-00-000 "Intellectual obligations"

Credit mega-account III-00-00-000 "Intellectual Capital" 3rd iteration: Regulation of intellectual capital by the amount of costs in the process of implementing the federal target program:

Debit of the mega-account III-00-00-000 "Intellectual Capital"

Credit mega-account I-00-00-000 "Intellectual Assets"

4th iteration: Regulation of the created intellectual capital and the size of the corresponding obligations and economic relations of the implementation of the central target program:

Mega-account debit III-00-00-000 "Intellectual capital"

Mega-account credit II-00-00-000 "Intellectual obligation»

5th iteration: Closing the mega Account I-00-00-00 "Intellectual assets", turnover on debit of the megaaccount I-00-00-000 minus turnover on credit of the mega account I-00-00-000. Obtaining a debit balance for the I-00-00000 "Intellectual assets" mega-account at the end of the period.

6th iteration: closing the mega-account II-00-00-000 "Intellectual obligations" at the stages of the federal target program implementation: the balance on the credit of the mega-account II-00-00-000 "Intellectual obligations" at the beginning of the period plus the turnover on the credit of the mega-account II-00-00-000 for the period and minus the turnover on the debit of the mega-account II-00-00-000 for the period, as a result, the balance of the mega-account II-00-00-000 "Intellectual obligations" at the end of the period is determined (positive balance in credit, and negative to debit).

7th iteration: closing the mega account III-00-00-000 "Intellectual capital" at the end of the period. The balance on the credit of the mega-account III-00-00-000 at the beginning of the period plus credit turnover on the mega-account III-00-00-000 for the period minus the debit turnover on the mega-account III-00-00-000 for the period is equal to the credit balance on the megaaccount III-00-00-000 (plus) or the debit balance for mega account III-00-00-000 (minus).

8th iteration: drawing up an intellectual megabalance for the implementation of the federal target program during and at the end of implementation:

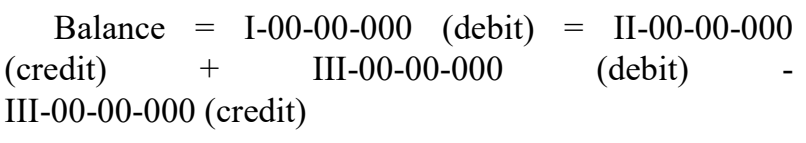


Table 1. Intelligent mega-balance.

\begin{tabular}{|l|l|}
\hline \multicolumn{1}{|c|}{ Asset } & \multicolumn{1}{c|}{ Passive } \\
\hline $\begin{array}{l}\text { Intellectual Assets } \\
\text { I-00-00-000 }\end{array}$ & Intellectual commitments \\
& $\begin{array}{l}\text { II-00-00-000 } \\
\text { Intellectual Capital } \\
\text { III-00-00-000 }\end{array}$ \\
\hline $\begin{array}{l}\text { Balance: intellectual } \\
\text { capital asset }\end{array}$ & $\begin{array}{l}\text { Balance: intellectual capital } \\
\text { liability }\end{array}$ \\
\hline
\end{tabular}

Off-balance sheet help:

Net intellectual assets $=$ Intellectual assets I-00-00$000 \quad$ - Intellectual obligations II-00-00-000

9th iteration: hypothetical implementation of intellectual assets, an intellectual mega-balance obtained as a result of the implementation of the federal target program in a fair assessment.

First option: fair prices of intellectual assets exceed the book value, i.e. the funding is used effectively.

Debit of the mega-account IV-00-00-00 "Synergistic effect" (for the amount exceeding the estimate).

Debit of the mega-account I-00-00-000 "Intellectual assets" (balance sheet estimate).
Credit mega-account I-00-00-000 "Intellectual assets" (balance sheet estimate).

Option two: the fair valuation of intellectual assets is lower than the balance sheet value, i.e. inefficient use of funding.

Debit of the mega-account I-00-00-000 "Intellectual assets" (balance sheet estimate).

Mega Account credit IV-00-00-000 "Synergy effect" (for the difference between the balance sheet and fair value).

The use of digital mechanisms for the execution of national projects provides a targeted solution to the following tasks at the stages of selecting of applications for grants, monitoring and summing up:

1. Obtaining resources for the purposes of national development of Russia with a focus on national capital. By our calculations, Pareto 20/80 and Harvard: 20/225 compliance creates an opportunity with \$ 26 trillion rubles receive national capital worth 30-40 trillion rubles.

2. Digital governance should create a critical mass of steps to put Russia on a growth trajectory, based on the fact that the world's universities create $20 \%$ of the national income, i.e. more than 20 trillion

Table 2. Hedged-risky digital mega-balance (thousand rubles).

\begin{tabular}{|c|c|c|c|c|c|c|c|c|c|c|c|c|c|}
\hline \multicolumn{2}{|c|}{ Balance sheet } & \multicolumn{2}{|c|}{ Hedged entries } & \multicolumn{2}{|c|}{$\begin{array}{c}\text { Hedged } \\
\text { balance sheet }\end{array}$} & \multicolumn{2}{|c|}{ Risks } & \multicolumn{2}{|c|}{$\begin{array}{l}\text { Integrated } \\
\text { risk }\end{array}$} & \multicolumn{2}{|c|}{$\begin{array}{l}\text { Hypothetical } \\
\text { integrations }\end{array}$} & \multicolumn{2}{|c|}{$\begin{array}{l}\text { Hypothetical } \\
\text { balance sheet }\end{array}$} \\
\hline Mega accounts & 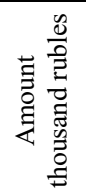 & Debit & Credit & .气̃ & 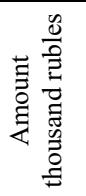 & Debit & Credit & .0̃ & 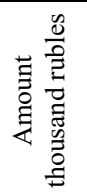 & Debit & Credit & 苛 & 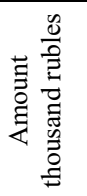 \\
\hline 1 & 2 & 3 & 4 & 5 & 6 & 7 & 8 & 9 & 10 & 11 & 12 & 13 & 14 \\
\hline $\begin{array}{l}\text { I. Non-current } \\
\text { assets }\end{array}$ & 22695 & & & I & 2695 & 8) 80 & & I & 2775 & & 12)2775 & I & \\
\hline II. Current assets & 3321 & $\begin{array}{c}\text { 1) } \\
6000 \\
\text { 2) } 200\end{array}$ & $\begin{array}{c}\text { 3) } 60 \\
\text { 4) } \\
\text { 3500 } \\
\text { 5) } 100\end{array}$ & II & 5861 & 6)150 & 9) 200 & II & 5811 & $\begin{array}{l}\text { 11)6300 } \\
\text { 12)2700 }\end{array}$ & $\begin{array}{l}\text { 11)5800 } \\
13) 2750\end{array}$ & II & 6250 \\
\hline $\begin{array}{l}\text { III. Capital and } \\
\text { reserves }\end{array}$ & 2859 & $\begin{array}{c}\text { 3)60 } \\
\text { 4)3500 } \\
\text { 5) } 100\end{array}$ & $\begin{array}{l}\text { 1) } 6000 \\
\text { 2)200 }\end{array}$ & III & 5399 & 9)200 & $\begin{array}{c}\text { 6) } 150 \\
\text { 7) } 240 \\
8) 80 \\
\text { 10)350 }\end{array}$ & III & 6019 & $\begin{array}{c}12) 75 \\
12) 183\end{array}$ & 11)489 & III & 6250 \\
\hline $\begin{array}{l}\text { IV. Long-term } \\
\text { duties }\end{array}$ & - & & & IV & - & - & & IV & & & & IV & \\
\hline $\begin{array}{c}\text { V. Short-term } \\
\text { duties }\end{array}$ & 3157 & & & $\mathrm{~V}$ & 3157 & $\begin{array}{c}\text { 7) } 240 \\
10) 350\end{array}$ & & $\mathrm{~V}$ & 2567 & 13)2567 & & $\mathrm{V}$ & \\
\hline Balance & 6016 & 9860 & 9860 & & 8556 & 1020 & 1020 & & 8586 & 1185 & 1185 & & 6250 \\
\hline Net assets & 2859 & & & & 5399 & & & & 6019 & & & & \\
\hline Net liabilities & & & & & & & & & & & & & 6250 \\
\hline Active zone & & & & & +2540 & & & & +620 & & & & +231 \\
\hline Passive zone & & & & & & & & & & & & & \\
\hline Neutral zone & & & & & & & & & & & & & \\
\hline $\begin{array}{l}\text { The state of the } \\
\text { reserve system, } \\
\text { taking into account } \\
\text { fair value }\end{array}$ & & & & & & & & & & & & & +3391 \\
\hline Security Margin & 5000 & & & & +399 & & & & +1019 & & & & +1250 \\
\hline
\end{tabular}


dollars.

3. Digital control over the execution of national projects eliminates even a hint of corruption, since is aimed not at justifying the expenditure (budget development and cash execution), but at a specific result in the amount of 4-14 trillion rubles created national capital.

\subsection{Digital mechanisms of backup system and risks managing}

Management of backup system and business risks is provided by a system of digital mega-balances in online mode: hedged, integrated risk, immunization, hedged risk, synergistic.

We will consider the mechanism of functioning on the basis of a hedged-risky mega-balance designed to manage the reserve system and the risks of a commercial enterprise (Table 1).

The digital mega-balance operates on the basis of mega-accounts, which are used as sections of the balance sheet:

○ mega-account I "Non-current assets»;

○ mega-account II "Current assets»;

○ mega-account III "Capital and reserves»;

○ mega-account IV "Long-term liabilities»;

○ mega-account V "Short-term liabilities".

Digital iterations are grouped into 3 groups:

1 st - hedged transactions providing management of the reserve system.

According to Professor Tkach V.I. there are more than 1000 weaver of the reserve system in the world economy, so they are grouped into 9 enlarged positions:

1. Reserve accounts

2. Management of asset and liability

3. Hedging

4. Insurance

5. Financial engineering tools

6. Guarantees and pledges

7. Control of risk with the help of protective mechanisms built into the operating system.

8. Joint venture, joint activity.

9. Finetri list mechanisms of the (over 300).

The thing is that the traditional management system of the reserve system reflects the use of only about $10 \%$ of the units in the balance sheet and off-balance accounting:
A. Balance accounts:

14 "Provisions for depreciation of material assets";

59 "Provisions for securing investments in securities";

63 "Provisions for doubtful debts";

82 "Reserve capital»;

96 "Reserve for future expenses".

B. Off-balance sheet accounts:

008 "Securing obligations and payments received";

009 "Securing obligations and payments issued";

C. Complimentary system:

21 "Provisions for outstanding transactions»;

64 "Provisions for warranties»;

87 "Guarantees issued and received".

(Recommended by a number of researchers).

The digital backup management system operates on the basis of 5 iterations, two of which increase the market value of capital, and three decrease, which makes it possible to reflect online more than 1000 possible aggregates of the backup system.

In our example, we get in real time:

1. Active zone of financial risk, taking into account the aggregates of the reserve system in the amount of +2540.0 thousand rubles $(5399.0-2859.0)$.

2. Active safety margin in the amount of +399.0 thousand rubles.

At active zone of financial risk and safety margins characterize the amount of monetary resources that can be used to repel competitors' threats, $\phi$ passive one-lack of resources.

The digital risk management system allows in real time to determine the impact of any possible risk on the state of the enterprise backup system, both as recommended by the Russian PBU, and in the tactical and strategic perspective, any other threats and risks:

PBU N/99 "Financial statements of the organization": Additional information in relation to borrowed funds, risk management;

PBU 12/2000 "Information by segment ": Reflection of general economic currency, credit, price, political risks by operating and geographical segments;

PBU 19/02 "Accounting for financial investments": When accepting assets for accounting as financial investments, it is necessary to organize the accounting pf financial risks (price changes, debtor's insolvency, liquidity risk). 
The concept of development of the Russian Federation for the average daily perspective requires identification of development risks (inadequacy of the real economic situation, incomparability of information, inconsistency of regulation, one-sided development). Organization of monitoring of factors that determine the risks of stability of the accounting and reporting system.

Developed and patented by Professor D.V. Kourseev, the digital management system of the backup system and risk management of a commercial enterprise provides:

1. Management digital accounting of the reserve system, integrated risks and risk situations, solvency, financial monitoring.

2. Strategic digital accounting of risk situations in the fractals of time and space, strategic accounting of property, innovation.

In our example, the state of the reserve system, taking into account the risks, is characterized by an active zone in the amount of +620 thousand. Rubles, the safety margin was +1019 thousand rubles.

\section{RESULTS}

The digital system for accounting and risk management and reserve system ensures the requirements of IFRS for information on risks that are subject to mandatory disclosure in the company's statements:

1) Market risk: quantitative information on risks with financial instruments: interest rates, exchange rates, commodity prices, prices and their impact on financial results;

2) Credit risk: the maximum possibility of losses under the worst sanctions. the company's policy on the claim of the pledget property;

3) Risk of the main activity: information on the financial position, capital and results of operations, indicating the need for capital, its placement, the effect of inflation;

4) Accounting risk: the nature of unforeseen losses and the assessment of their possible magnitude. If company are not in a position to assess possible losses, then this should be clearly indicated in the financial statements.

The result of the functioning of the reserve system is determined by the synergetic effect or anergism, the digital program is patented by Professor Tkach V.I. weaved in Rospatent of the Russian Federation in the form of "Digital synergetic mega-balance" and in our example amounted to +1250 thousand rubles. (synergistic effect of functioning).
As a result, the digital backup system and risk management system is pre-determined and allows avoiding any threats in real time:

- compensation for the reduction in the cost of raw materials, materials, fuel, work in progress, finished products from market prices;

- compensation for losses from resources invested in securities;

○ compensation for losses on doubtful debts;

○ for the purposes stipulated by the charter;

- evenly include costs in costs;

○ guarantees of own payments;

○ guarantees of payments of third parties;

○ compensation for losses under contractual relations;

- compensation for losses under warranty obligations.

\section{REFERENCES}

[1] I. Averchev, How to evaluate the efficiency of the company, http:www.class.ru/uchet/effekt_kompany.html.

[2] I. M. Ageev, Modeling, financial and management accounting in the conditions of risk and uncertainty, Rostov n/D, 2000, pp. 191.

[3] E. A. Aksenova, Organization of financial and management accounting in road construction: monograph, Rostov n/D: RGSU, 2004, pp. 209.

[4] V. A. Alyabyeva, Factors and ways to improve the financial stability of the organization. Belgorod: BSTU, 2oyu, pp. 45.

[5] I. N. Bogataya, Strategic accounting of enterprise ownership. Rostov n/D: Phoenix, 2001, pp. 240.

[6] K. S. Blagovisnaya, Organization of hedge accounting at the enterprise: study guide. Manual, Rostov-on-Don: DSTU, 2017, pp. 62.

[7] V. V. Bocharov, Financial engineering. St. Petersburg.; Peter, 2004, pp. 400.

[8] V. Pol, The truth machine. Blockchain and the future of humanity, Moscow: Mann, Ivanov and Feber, 2018, pp. 320.

[9] E. Gamma, R. Helm, R. Johnson, J. Vlissides, Object-oriented design techniques. Design patterns. St. Petersburg: Piter, 2018, pp. 368.

[10] P. Dominguez, The supreme algorithm: how 
machine learning will change our world, scientific M.: Mann, Ivanov and Ferber, 2016, pp. 336.

[11] M. G. Delyagin, The world crisis: The general theory of globalization: A course of lectures. - 3rd ed., reprint. and add. M.: INFRA-M, 2003, pp. 768.

[12] G20 Digital Economy and Cooperation (EB/OL). 2016, htpp:www.cac.gov.cn/201609/29/c_1119648520.html.

[13] E. A. Krainova, V. I. Tkach Traditional and engineering methods of accounting: textbook. method. Manual, Don State University. Tech. univ. - Rostov-on-Don: DSTU, 2017, pp. 48.

[14] O. I. Kolvakh, Situational matrix modeling in accounting and balancing: monograph, M.: Vuzovskaya kniga. 2010, pp. 336.

[15] O. I. Kolvakh, V. Y. Kopytin, Adaptive models of accounting and financial reporting in the system of credit institutions (concept, methods and information and technical support). Rostov $\mathrm{n} / \mathrm{D}$ : Publishing house "Terra". 2002, pp. 151.

[16] G. E. Krokhicheva, Virtual accounting: concept, theory and practice. M.: Finance and statistics, 2003, pp. 176.

[17] G. E. Krokhicheva, Corporate network accounting and reporting: the concept, methodology and organization: Dissertation of Doctor of EconomicsRostov n/D, 2004, pp. 367.

[18] E. V. Kuznetsova Improving of accounting in commercial organizations of water transport: monograph. Rostov-on-Don: RSEU "RINH", 2004, pp. 171.

[19] D. V. Kurseev, Agency relations in the processes of external and trust management of property: accounting modeling and accounting, Rostov-onDon: RGSU, 2003, pp. 142.

[20] V. V. Lesnyak, Organization of strategic management accounting at industrial enterprises: theory and practice: a monograph. Rostov-n/D: RGSU, 2006, pp. 195.

[21] L. Guojie, Digital Economy Drives Innovative Development (N), People's Daily, 2016.

[22] Lileeva L.R. Financial, managerial, strategic accounting in communications and telecommunications organizations: theory and practice. Rostov-on-Don: IPO RGPU, 2006, pp. 212.

[23] N. P. Lyubushin, Analysis of the financial condition of the organization. Moscow: EKSMO, 2013.

[24] A. N. Maksimenko, Organization of network situational (event) accounting in commercial organizations, Rostov-n/D: RGSU. 2008, pp. 208.

[25] E. A. Markaryan, G. P. Gerasimenko, S. E. Markaryan, Financial analysis: textbook. allowance. Moscow: FBK-PRESS Publishing House, 2013.

[26] J. F. Marshal, Bansal Vipul K. Financial engineering: $a$ complete guide to financial innovation, M.: INFRA-M, 1998, pp. 784.

[27] M. Huaten, China's digital Transformation. Experience of transforming the infrastructure of the national economy, Chinese-M.: Intellectual Literature, 2019, pp. 250.

[28] M. Mobussin, More than you know: An unusual view of the world of finance, M.: Alpina Publisher, 2018, pp. 380.

[29] D. Moshella, Guidebook to the digital future: Branches of organization and profession, EnglishM.: Alpina Publisher, 2020, pp. 215.

[30] E. I. Murugov, Accounting and analytical support for the management of solvency and the reserve system of the enterprise. Rostov-n/D: RGSU, 2003, pp. 137.

[31] M. R. Mathews, M. H. B. Perera, Theory of accounting: Textbook. M.: Audit_UNITI, 1999, pp. 663.

[32] V. V. Pigunova, Application of engineering systems in accounting for solvency and financial stability of the enterprise: textbook. Method, manual, Don State Technical University - Rostovon-Don: DSTU, 2017, pp. 55.

[33] T. Pikety, Capital in the Twenty-first century, M. Ad Marginem Press, 2016, pp. 592.

[34] I. R. Sukharev, Stereo accounting. M.: CPI "Moscow", 2014.

[35] B. Ryan, Strategic accounting for the head, M.: Audit, UNITY, 1998, pp. 616.

[36] N. P. Rudnenko, Management and strategic accounting solvency: theory and practice, Rostovn/D: RGSU 2007, pp. 229.

[37] E. Yu. Rusina, Analysis and control of the financial condition with the use of accounting engineering tools: monograph. Rostov-on-Don: RGSU, 2013, pp. 195. 
[38] V. I. Tkach, Digital behavioral economy: technologies and platform solutions: textbook / V.I. Tkach; Don State Technical University - Rostovon-Don: DSTU, 2019, pp. 482.

[39] V. I. Tkach, University: engineering management: qualimetric monograph, Rostov-n/D: Publishing center of DSTU, 2016, pp. 379.

[40] V. I. Tkach, G. E. Krokhicheva, M. Yu. Anikeev, E. L. Arkhipov, Accounting for hedging operations. Rostov-n/D: RSSU, 2004, pp. 158.

[41] V. I. Tkach, Digital accounting and management of the solvency of an individual entrepreneur: textbook, Don State Technical University - Rostovon-Don: DSTU, 2018, pp. 84.

[42] V. I. Tkach, Digital accounting tools in the activities of medical organizations: textbook. Manual, Don State Technical University - Rostovon-Don: DSTU, 2018, pp. 68.

[43] V. I. Tkach, Digital economy and management: monograph. Rostov n/D: Publishing Center of DSTU, 2018, pp. 440.

[44] V. I. Tkach, Digital accounting: engineering chart of accounts, network technologies and platform solutions. - Rostov n/D: DSTU, 2020, pp. 228.

[45] V. I. Tkach, G. E. Krokhicheva, Management aspect of financial accounting: international practice, Rostov n/D: RGSU, 2008, pp. 58.

[46] V. I. Tkach, Engineering theory of accounting: qualimeter: textbook, Rostov n/D: RGSU, 2013, pp. 428.

[47] V. I. Tkach, Initiative seminar on Russia, Paris: European Commission of the EEC, 1997, pp. 82.

[48] V. I. Tkach, Behavioristic accounting of human capital: monograph. - Rostov-on-Don.: RGSU, 2014, pp. 44.

[49] V. I. Tkach, T. O. Grafova, M. V. Shumeyko, N. P. Rudenko, Accounting engineering: concept, theory and practice: monograph. Rostov n/D: RGSU, 2009, pp. 144.

[50] B. Franks, Revolution in analytics: How to improve your business with the help of operational analytics in the era of Big Data, Moscow: Alpina Publisher, 2016, pp. 316.

[51] Financial management: theory and practice: textbook, Moscow: Perspektiva, 2011.

[52] E. S. Hendriksen, M. F. Van Breda, Theory of accounting. M.: Finance and Statistics, 1997, pp.
576.

[53] Digitalization: Practical recommendations for transferring business to digital technologies, M: Alpina Publisher, 2019, pp. 252.

[54] M. V. Shumeyko, Concepts and methodology of accounting and engineering: monograph, Rostovn/D: RGSU, 2008, pp. 188.

[55] P. E. Shumilin, Accounting and audit of enterprise reorganization. Rostov-n/D: RSEU "RINH", 2005, pp. 142 .

[56] A. S. Ishikawa, M.Silverstein, M. Jacobson, I. Fiksdahl-king and Sh. Angel, A. Pattern, Language. Oxford Universiti Press, New York. 1977, pp. 460.

[57] R. Coase, The Firm, the Market and the Law. Chicago. 1988, pp. 185

[58] R. Coase, Firm, Market and law. M; Delo LTD with the participation of the publishing house Catallaxy. 1993.

[59] R. Freeman, Edward and McVea, John, A Stakeholder Approach to strategic management 1-2 (2001).

[60] J. Galanos, Systeme information comptable et modeles de gestion mergents, These de: doctorate en sciences de gestion, IAE de Nice, 1991.

[61] H.T. Johnson, R.S. Kaplan, Relevance Lost: The Rise and Fall of Management Accounting. Boston: Harvard Business School Press, 1987.

[62] K. Langfield-Smith, Strategic management accounting: how far have we come in 25 years? Accounting, Auditing \& Accountability Journal, 21(2) (2008) pp. 204-228.

[63] The Information Technology and Innovation Foundation. A Policymaker's Infrastructure (R), http://www.infrastructureusa.org/aolicymakersguide-to-digital-infrastructure.

[64] M. Knickrehm, B. Berthon,' P. Daugherty, Digital Disruption: The Growth Multiplier (R). Accenture Strategy, 2016.

[65] World Economic Forum. He Global Information Technology Report 2016: Innovating in the Digital Economy (R). 2016.

[66] McKinsey, Digital globalization: The New Era of Global Flows (R). 2016.

[67] European Digital Progress Report (EB/OL). https:/ec.europa.eu/dlgltalsingle- 
market/en/european-digital-progress-report.

[68] European Commission. eGovernment Action Plan (EB/OL). https://ec.europa.eu/digital-singlemarket/en/egovernment-action-plan-digitisingeuropean-industy.

[69] Industrial Platforms and Large Scale Pilots (EB/OL). $\quad$ https://ec.europa.eu/digital-singlemarket/en/industrial-platforms-and-large-scalepilots.

[70] Coordination of European, National \& Regional Initiatives (EB/OL). https://ec.europa.eu/digitalsingle-market/en/cordination-europeannationalregional-initiatives. 